\title{
EHMTI-0315. AMG 334, the first potent and selective human monoclonal antibody antagonist against the CGRP receptor
}

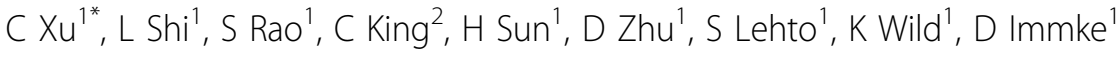 \\ From 4th European Headache and Migraine Trust International Congress: EHMTIC 2014 \\ Copenhagen, Denmark. 18-21 September 2014
}

\section{Background}

Clinical studies with multiple CGRP receptor antagonists reported that CGRP receptor antagonism is effective in acute migraine reversal. Using XenoMouse ${ }^{\circledR}$ Technology, we successfully generated a group of human monoclonal antibodies $(\mathrm{mAb})$ that specifically target the human CGRP receptor.

\section{Aim}

to characterize the pharmacological properties of AMG 334 , one of the mAbs currently in clinical development for migraine prevention

\section{Methods}

We used [125I]-CGRP and [125I]-AMG 334 binding assays to measure AMG 334/CGRP-receptor interactions, cell-based cAMP assays to study functional activity and selectivity of AMG 334, and a laser Doppler model in cynomolgus (cyno) macaque to assess the pharmacodynamic effects of blocking capsaicin-induced increases in dermal blood flow with AMG 334.

\section{Results}

AMG 334 is a potent inhibitor of [125I]-CGRP binding to the human CGRP receptor with a Ki of $0.02 \mathrm{nM}$. It exhibited full inhibition of CGRP-stimulated cAMP production with an IC50 of $2.3 \mathrm{nM}$ in cell-based functional assays. Potency of AMG 334 at the cyno CGRP receptor is similar to that at the human receptor, but with significant reduced potency at dog, rabbit and rat receptors. AMG 334 also demonstrates $>5000$-fold selectivity over other closely related receptors in the family. The receptor kinetics

${ }^{1}$ Neuroscience, Amgen Inc., Thousand Oaks, USA

Full list of author information is available at the end of the article studies using [125I]-AMG 334 reveals a dissociation t1/2 off of $67 \mathrm{~min}$.

In the cyno study, AMG 334 produces a significant and sustained inhibitory effect on capsaicin-induced increase in dermal blood flow.

\section{Conclusion}

AMG 334 is a potent and selective antibody against the human CGRP receptor with potential for migraine prevention.

Authors' details

${ }^{1}$ Neuroscience, Amgen Inc., Thousand Oaks, USA. ${ }^{2}$ Therapeutic Discovery,

Amgen Inc., Thousand Oaks, USA.

Published: 18 September 2014

doi:10.1186/1129-2377-15-S1-G43

Cite this article as: Xu et al:: EHMTI-0315. AMG 334, the first potent and selective human monoclonal antibody antagonist against the CGRP receptor. The Journal of Headache and Pain 2014 15(Suppl 1):G43.

Submit your manuscript to a SpringerOpen ${ }^{\bullet}$ journal and benefit from:

- Convenient online submission

- Rigorous peer review

- Immediate publication on acceptance

- Open access: articles freely available online

- High visibility within the field

Retaining the copyright to your article

Submit your next manuscript at $>$ springeropen.com (c) 2014 Xu et al; licensee Springer. This is an Open Access article distributed under the terms of the Creative Commons Attribution License (http://creativecommons.org/licenses/by/2.0), which permits unrestricted use, distribution, and reproduction in any medium, provided the original work is properly cited. 